\title{
Capabilities of subsidence detection on mining areas in Upper Silesian Coal Basin using Sentinel-1A data acquired in Interferometric Wide Swath Mode
}

\author{
Hubert Malik \\ AGH University of Science and Technology; al. A. Mickiewicza 30, 30-059 Krakow, Poland; e-mail: hmalik@geol.agh.edu.pl \\ (c) 2016 Authors. This is an open access publication, which can be used, distributed and reproduced in any medium according \\ to the Creative Commons CC-BY 4.0 License requiring that the original work has been properly cited.
}

Monitoring of the Earth Surface using SAR satellite radar is an increasingly used tool in case of natural and anthropological hazards (Perski 1999). Differential Interferometry SAR (DInSAR) and Persistent Scatterer Interferometry SAR (PSInSAR) are satellite SAR radar interferometry methods. These are well-known and widely used tools for detecting ground deformation (Porzycka \& Leśniak 2010). New generation of SAR antennas provide the imagery with sub-meter resolution. It allows for computing very accurate interferograms capable for slow and dynamic subsidence detection over even small areas. These properties of SAR technology are very important in case of heavily populated mining regions, where comes to damage to residential buildings (Mirek 2012). Studies presented in this paper refer to the Upper Silesian Coal Basin (South Poland), which is vulnerable to the subsidence phenomenon. The aim of this study was to determine the applicability of the interferometric analysis of different zones in Upper Silesian Coal Basin. In this area subsidence occurs at different rates and can be divided into slow displacement with wide range and dynamic subsidence of small areas. In the described work the analysis of ground deformation was performed using Sentinel-1A data acquired in Interferometric Wide Swath Mode (IWS) with 12 days revisit and $5 \times 20$ meters ground resolution. Free and open access to Sentinel-1 satellite data are granted for the Copernicus programme. It is focused on global coverage and quick data delivery (ESA website). The obtained results show the capabilities and limitations of this technology in case of vertical ground deformation velocity compared to its range. The relationship between the spatial resolution of the imagery and the dynamics of subsidence was presented. Finally the possibility of using PSInSAR method with Sentinel-1A data was presented (Strzelczyk \& Porzycka-Strzelczyk 2014).

\section{REFERENCES}

ESA, http://www.esa.int/Our_Activities/Observing_the_ Earth/Copernicus/Sentinel-1/Introducing_Sentinel-1m [access: 15.02.2015].

Mirek K., 2012. Satellite radar interferometry (InSAR) used for estimation of ground subsidence in mining areas Upper Silesian Coal Basin Case Study. Polish Journal of Environmental Studies, 21, 5A, 312-316.

Porzycka S. \& Leśniak A., 2010. Analiza czasowa powolnych deformacji terenu na obszarze Zagłębia Dąbrowskiego. Przeglad Górniczy, 66, 6, 70-75.

Perski Z., 1999. Zakres interpretowalnosci osiadań terenu za pomocą satelitarnej interferometrii radarowej (InSAR). Archiwum Fotogrametrii, Kartografii i Teledetekcji, 9, 191-199.

Strzelczyk J. \& Porzycka-Strzelczyk S., 2014. Identification of coherent scatterers in SAR images based on the anaysis of polarimetric signatures. IEEE Geoscience and Remote Sensing Letters, 11, 4, 783-787. 